\title{
Long Noncoding RNA FGD5-ASI Acts as a Competing Endogenous RNA on microRNA-383 to Enhance the Malignant Characteristics of Esophageal Squamous Cell Carcinoma by Increasing SP I Expression [Retraction]
}

Gao J, Zhang Z, Su H, Zong L, Li Y. Cancer Manag Res. 2020;12:2265-2278.

The Editor and Publisher of Cancer Management and Research wish to retract the published article. Concerns were raised over alleged image duplication in Figures 5B and 7B with similar images from unrelated articles, specifically:

- Figure 5B, panel Eca109 si-FGD5-AS1+antagomirNC appears to have been duplicated with a similar image in Figure 2C from Cheng et al, 2020 (https:// doi.org/10.2147/OTT.S218876).

- Figure 7B appears to have been duplicated with similar images from Figure $7 \mathrm{~b}$ in $\mathrm{Bi}$ et al, 2020 (https://doi.org/10.1080/15384101.2020.1731645).
The authors responded to our initial queries but were unable to provide a satisfactory explanation for the alleged duplication and could not provide satisfactory original data for their study. The Editor advised for the article to be retracted.

Our decision-making was informed by our policy on publishing ethics and integrity and the COPE guidelines on retraction.

The retracted article will remain online to maintain the scholarly record, but it will be digitally watermarked on each page as "Retracted".
Cancer Management and Research is an international, peer-reviewed open access journal focusing on cancer research and the optimal use of preventative and integrated treatment interventions to achieve improved outcomes, enhanced survival and quality of life for the cancer patient.
The manuscript management system is completely online and includes a very quick and fair peer-review system, which is all easy to use. Visit http://www.dovepress.com/testimonials.php to read real quotes from published authors. 